\title{
Analysis of traditional Pedi religious songs for curricular application in primary school
}

\author{
Author: \\ Morakeng E.K. Lebaka \\ Affiliation: \\ ${ }^{1}$ Old Testament Studies, \\ University of Pretoria, South \\ Africa

\section{Correspondence to:} \\ Morakeng Lebaka \\ Email: \\ edwardlebaka@gmail.com \\ Postal address: \\ PO Box 14193, Hatfield 0028, \\ South Africa \\ Dates: \\ Received: 18 Mar. 2014 \\ Accepted: 16 July 2014 \\ Published: 08 Dec. 2014 \\ How to cite this article: \\ Lebaka, M.E.K., 2014, \\ 'Analysis of traditional Pedi \\ religious songs for curricular \\ application in primary \\ school', In die Skriflig 48(1), \\ Art. \#1822, 8 pages. http:// \\ dx.doi.org/10.4102/ids. \\ v48i1.1822

\section{Copyright:} \\ (C) 2014. The Authors. \\ Licensee: AOSIS \\ OpenJournals. This work is \\ licensed under the Creative \\ Commons Attribution \\ License.
}

The Bapedi is an ethnic group in South Africa whose traditional music is not welldocumented. For this article, 31 traditional Pedi religious songs from 11 elderly Bapedi women in Sekhukhune, Limpopo Province, South Africa were collected and analysed. They were analysed using religious, musicological and contextual perspectives, and two choruses were selected. Eight Sepedi-speaking children from a school choir at Baxoxele Primary School in Soshanguve were observed whilst learning these two choruses. Repetition was used as a powerful, rhetorical and expressive device, skilfully employed to express and internalise faith and to impart dominant emotions. Informal discussions with teachers indicated that the children showed an improvement in their concentration and attitude to schoolwork. Learning these two choruses also unlocked some creative talent and improved their social skills. The joyous nature, rhythmic foundation, harmonic simplicity, and combination of intellect and emotion as well as the repetitiveness and briefness of these songs appealed to both children and adults. It was concluded that for the preservation of traditional Pedi religious music and culture there is an urgent need for the collection and documentation of traditional Pedi religious songs. In recognising their identity, such songs could contribute to the attitudes and cultural values of Sepedi-speaking children. Similar projects are suggested for the other 10 language groups in South Africa.

Analisering van tradisionele godsdienstige Pedi-liedere vir gebruik in die laerskool kurrikulum. Die Bapedi is 'n etniese groep in Suid-Afrika wie se tradisionele musiek nie goedgedokumenteer is nie. Vir hierdie artikel is 31 tradisionele godsdienstige Pedi-liedere van 11 bejaarde Bapedi vroue in Sekhukhune, Limpopo Provinsie, Suid-Afrika, ingesamel en ontleed. Hierdie liedere is volgens godsdienstige, musiekwetenskaplike en kontekstuele perspektiewe ontleed en twee kore uit die liedere is daarna gekies. Agt Sepedi-sprekende kinders van die Baxoxele Primêre Skool in Soshanguve se skoolkoor, is waargeneem terwyl hulle hierdie twee kore aangeleer het. Herhaling is gebruik as 'n kragtige, retoriese en betekenisvolle hulpmiddel, vaardig toegepas om uitdrukking aan geloof te gee en 'n verdieping daarvan te bewerkstellig sowel as om grootliks emosie daaraan te verleen. Informele gesprekke met onderwysers het aangedui dat die kinders se konsentrasie en hulle houding teenoor skoolwerk verbeter het. Die aanleer van hierdie twee kore het ook hulle kreatiwiteitstalent ontsluit en hulle sosiale vaardighede verbeter. Die vrolike en ritmiese aard, harmoniese eenvoud, die kombinasie van intellek en emosie sowel as die herhaling en bondigheid van hierdie kore het ' $n$ effek op kinders sowel as volwassenes gehad. Die gevolgtrekking was dat daar ' $n$ dringende behoefte is om soortgelyke liedere te versamel en te dokumenteer met die doel om tradisionele godsdienstige Pedi-musiek en -kultuur behoue te laat bly. Deur erkenning te gee aan die aard van sulke liedere kan bygedra word tot ' $n$ positiewe houding van Sepedi-sprekende kinders teenoor kulturele waardes. Soortgelyke projekte vir liedere van die ander 10 taalgroepe in Suid-Afrika word voorgestel.

\section{Introduction}

In Africa, music and dance are interwoven with the strong inter-subjective ethical demand of sharing: Ubuntu (Westerlund 1999:101). Mbiti (1969:2), for example, acknowledges that to be human is to belong to the whole community. This involves participating in the beliefs, ceremonies, rituals and festivals of that community. In consonance with the above view, Akuno (2005:72) describes African music as an expression, a work of art and a performance. In his view, African music is a human behaviour involving people with their communities - an agent of socialisation. He is convinced that, since African music reflects and expresses culture, it embodies a people's total existence: beliefs, philosophy (worldview), religion, norms, mores, language, expressions, relationships and aspirations. Within this context, traditional religious songs have a special significance in terms of Southern African cultural values. Therefore, for the preservation of the 
Bapedi cultural heritage, the collection and documentation of traditional Pedi religious songs from elderly Bapedi people should be prioritised.

Such an investigation in the Pedi tradition has hitherto not been attempted. Documentation of traditional Pedi religious songs is of importance to enable the retention of Pedi cultural heritage. Culture is defined as a historically created system of explicit and implicit designs for living, which tends to be shared by all, or especially designated members of a group at a specific point in time (Balasuriya 2002:93). Exposure to traditional Pedi religious songs can lead to proper assessment, aesthetic appreciation and a clear understanding of the Bapedi emotional expression of religion.

Mugambi (1994:9-16) approaches theologising in Africa from two perspectives, which are mutually dependent. Firstly, he suggests the collection of data about African societies, this means fresh studies concerning various religions and cultural systems, must be embarked on. Secondly, and consequently, the results from the foregoing investigations should be used in biblical interpretation and theologising. Mugambi's call echoes Agbeti's (1972:6-7) and has been undertaken at various levels in African studies and theology. The need for authenticity is increasingly motivating such studies. This article complies with this endeavour, since traditional Pedi religious songs are collected and assessed. The purpose of this article is to collect and analyse traditional Pedi religious songs for curricular application in the primary school setting.

\section{Conceptual framework}

This article is based on a contextual approach to traditional Pedi religious music, aimed at finding a way to study children and childhood that both respects and accurately represents the voices of children whilst simultaneously working within the bounds of academia. This research reflects Spradley's ethnographic cycle - create ethnographic questions, collect data, make records, analyse data - which then returns to the initial questions on a more structural level (Spradley 1980). In approximation to this article other scholars have employed an ethnographic approach. Included in this approach are Boas (1906; 1920), Stocking (1974; 1979), Rohner and Rohner (1969), Smith (1959), Lesser (1981) and Codere (1966). For example, in his mature phase, Boas (1920) was quite clear about the value of particular kinds of ethnographic evidence. He aimed at producing ethnographic material that reflected the 'mind' of the people studied (Stocking 1974). Boas criticised ethnographic accounts for depending on subjective opinions of collectors, which made them superficial and unscientific. Instead he argued for accounts that showed what 'the people [...] speak about, what they think and what they do', recorded by the ethnographer in 'their own words' (Boas 1906:642; see also Rohner \& Rohner 1969:xxiii). The only way to achieve this was through the collection of artefacts and the extensive recording of texts in the native language. It has been argued that Boas' approach to the collection of ethnographic material reflected his 'natural science' approach to material
(Smith 1959:53; see also Lesser 1981:7). Stocking (1979), however, has cogently argued that Boas' approach reflected his humanistic as much as his scientific training. Whatever the origins and motives of Boas' work, his aims were quite clear: raw data was needed before theory.

Although Boas' aims in ethnographic collection were clear, his methods were never explicitly stated (Smith 1959:53; Codere 1966:xiii) - by 'method' Boas usually referred to analysis rather than field techniques (Boas 1920:313). This research is, however, distinguished from Boas $(1906 ; 1920)$ thematically and contextually as evidenced by the variation of study subjects. Moreover, this research has endeavoured to close the gap of parallelism between traditional African music and Western music by affording students the opportunity to play these songs using Western brass instruments. Ultimately, this is an academic approach to musicological and ethnomusicological research.

This article is enriched by the general agreement amongst scholars such as Nzewi (2005), Campbell (2002), Kwami, Akrofi and Adams (2003) as well as Joseph and Van Niekerk (2007). For example, Nzewi (2005:vii) believes that African music education needs to be redefined. He argues that the post-colonial African classroom should therefore derive its principles, structure and content from Africa's tradition musical heritage. On a similar note, Campbell (2002:57) states that the acquisition of musical repertoire and a set of techniques for making and responding to music should be available to children formally and informally - both in and outside school. In her opinion, the musical knowledge should be mediated to the children in a large variety of ways. In consonance with the above view, Kwami and his co-authors see the current South African curriculum as more holistic than previously. They argue that, although improvement has been made, it has yet to be 'fully exploited', even though it 'recognises African musical arts as something that must involve integration in the arts as well as cultural integration' (Kwami et al. 2003:270). Their arguments about musical arts education in the new South African curriculum are further exposed in rural schools that have little access to musical training for teachers or the necessary tools for musical training as outlined in the current curriculum (such as access to musical instruments). Joseph and Van Niekerk (2007:488) endorse this observation by suggesting that Africa's traditional musical heritage should be recognised by the current South African curriculum. They maintain that through music, children learn about themselves and 'retain, maintain and renegotiate their identities'.

\section{Objectives}

Since the preliminary research has revealed that traditional Pedi religious songs are not well-documented, the prime objective of the article is to collect unknown and fast disappearing traditional Pedi religious songs, as recalled by elderly Bapedi who were children in the 1930s and 1940s. However, it was not only the aim to document the oral heritage of traditional Pedi religious songs, but also to: 
1. analyse the 31 collected songs in order to select two short choruses suitable for young children

2. demonstrate the importance of the two short choruses in the classroom situation

3. critically examine whether the two choruses selected from traditional Pedi religious songs are relevant for the primary school curriculum within the context of enriching attitudes and cultural values of children.

\section{Research method and design}

The author belongs to the Pedi culture. He therefore has experience in life situations of the Pedi environment. By studying their traditional religious songs in their context(s), it is been managed to analyse the songs in terms of form and language use, contexts, content as well as functions descriptive assessment (Fontana \& Frey 1994). This contextual approach has led to the achievement of research objectives. Therefore, on the basis of the foregoing, this article adopted the qualitative approach in the collection and analysis of data (Mouton 2001:108; Frankle \& Wallen 1993). Data from this qualitative approach were analysed in order to select two short choruses suitable for young children. Thus, this article is contextual as it considers the local context (Pedi culture) and the influence of biblical and Israelite culture on the people. In order to situate the article theoretically and generate the conceptual framework, secondary data was consulted and assessed. Secondary evidence included written sources like books, journal articles, articles, et cetera. The literature aspect is complemented by field research conducted through interviews, observation and recording (Du Toit 1998:378).

The methodology primarily used in the collection of data for this article was based on participant observation. Data was collected in many settings - primarily in non-formal, outdoor settings. Most of the interviews took approximately two hours each. An initial and follow-up interview were held with each elderly woman. The subjects for this article were purposely identified because of their knowledgeable and informative qualities. The sample size of subjects consisted of 11 elderly women aged between 73 and 85, and eight Sepedispeaking children aged between 10 and 11 from a school choir at Baxoxele Primary School in Soshanguve. Together these made up a total of 18 subjects. During the author's association with the subjects in Sekhukhune district, they corroborated the data on traditional Pedi religious songs and their cultural and religious functions.

This article is therefore a descriptive, expository and interpretative study.

\section{Results}

\section{Field observations}

\section{Observed significance of traditional religious songs amongst the Bapedi}

The observations made during the field research led to the following question: What role do traditional religious songs play in the life and spirituality of the Bapedi? Before this question could be answered, some basic notions of the Pedi society and religion need to be considered first.

The Pedi society is organised according to an order of different clans and tribes, which have a Kgoši [the chief] as their leader. Family bonds are strong, as one can notice on the occasion of funerals, which are usually attended by everyone who is somehow related to the deceased's family. Part of that is due to the Pedi understanding of botho, which means 'humaneness' (caring and sharing). Botho is the reflection of the view that 'what counts is the human being' (Lapointe 1995:254). The practical interpretation of music is part of the essence of the Pedi existence, botho. The community of all people forms the backbone of the Pedi society, based on an understanding of a relatedness of persons in community. Thus, for the Bapedi, all life is sacred - life and religion are seen together (Mönnig 1967:54).

The significance of music in the Pedi life and religion is linked to the coherence between the secular and the sacred, deep communal experiences, the emotional expression of religion as well as the value of symbolic communication through rituals. Singing plays an important role in Pedi life. Van der Hooft (1979:150) infers that, to the people of Africa, dancing and music-making serve as a means by which they relax and enjoy themselves. In Africa, dance and music are essential elements of life. For example, commemorations of important historical events are lively with the singing of praise songs, drumming, clapping and dancing. This is confirmed by Levine (2005:143), who mentions that in the Pedi culture men chant praise songs (direto) resembling historical epics in the still of the night. They usually recall events pertaining to tribal chiefs and heroes. Levine further mentions that, whilst men use praise poetry to narrate the past glories of the Bapedi, women use folktales to explore their world. These tales are ancient stories that have been passed on through the generations. Indeed, these activities determine their style of living. Indigenous stories and songs are useful sources for learning about attitudes and values as well as cultures and generations (Burton \& Chacksfield 1979:70; Potgieter 2006:vi).

The Sepedi term generally used to describe music is mmino. Referring to the manner of dancing as an expression of joy (Snyman, Shole \& Le Roux 1990:95; Kgasa \& Tsonope 1995:157), mmino is a very concrete description of music. It is related to dance as its root, the verb go bina [to dance] or go phasa [to venerate] (Snyman et al. 1990:11). Another verb, go opela, means 'to sing' (Kgasa \& Tsonope 1995:204) whilst the noun kopelo [hymn] signifies a song written in praise of God (Snyman et al. ibid:76). These terms, all used in Sepedi to refer to such a complex and vital phenomenon as music, indicate that different societies have their own specific concepts of music (Oosthuizen 1976:98). They display specific behavioural patterns towards making music and responding to music. They order their musical sound patterns in a specified manner. These patterns are determined by the commonly held concepts and related behaviour in a specific culture. Music is closely assigned to the reality of everyday life and concrete religious practice - a fact that makes it necessary to transport messages or emotions. 


\section{Analysis of data}

The 31 songs collected from Bapedi women were analysed specifically to select two short choruses appropriate for use in education of primary school children. These two choruses were in turn analysed.

This analysis comprises a few important elements of the actual music in the two choruses selected for primary school curriculum, exemplified by traditional Pedi religious music. These two choruses were: 'Re tšwa ka mo, re ya ka mo' ['We are moving from one place to the other'] and 'Ngwanešo o sa diegelang?' ['My brother/sister, why are you undecided?'].

\section{Descriptive assessment of 'Re tšwa ka mo, re ya ka mo'}

The first song, 'Re tšwa ka mo, re ya ka mo', is analysed and described below. The procedure for assessment is derived from the form and language use, contexts, content and functions (see Figure 1).

\section{The text and translation follows below:}

1. Re tšwa ka mo, re ya ka mo [We are moving from one place to the other]

2. Re ya rutwa lentsu la Modimo [We are receiving ministry about the Word of God]

3. A re yeng faseng la Kanana [Let us go to Canaan]

4. Faseng la bo ntata rona [Our forefathers' land].

The song was recorded by the author on a field trip at Lobethal Church Centre, Sekhukhune area in the Limpopo Province, on 13 January 2008.

This song is characterised by joy, interaction, concentration, expression, self-confidence and imagination. It has a fast tempo and is full of movement, including dance steps. Joy is both an attitude and a most exciting divine gift. It is an attitude stemming from confidence and trust in their God. Joy brings with it enthusiasm for life, determination to persevere and a desire to encourage others. There are many rich, indigenous, religious ideas occurring in this song: trust, hope, praise, love and survival. In this song praying, the recognition of God as their Saviour, is enriched by music (singing).

Musical repetition in its simplest form is evident in this song. The rather simple musical nature (cyclical form of repetitiveness and basic contents) makes this song accessible to both adults and children. Repetition serves as useful means by which the singers emphasise and project the principal idea of this song to the listening audience. In this song performance, 'Re tšwa ka mo, re ya ka mo' (lines 3 and 4) is the phrasal idea that constitutes the main theme. Repetition is a powerful, rhetorical and expressive device, skilfully employed by the singers to hammer keywords home in order to implant dominant emotions in the mind of the audience.

In many African languages there are no separate terms for music and dance: '[T]he two are seen to be indivisible. In a way dancing is rhythm made visible' (Karolyi 1998:6). Whilst performing this song, dancing involved rhythmic expressions, as diverse as the simple clapping of hands or stamping of feet, and expressive body movements. The careful use of figurative words with powerful associative meanings was shown in this song, and the text possessed variation in poetic expression. The song contained several figures of speech - forms of imagery that required serious thinking and familiarity with Sepedi to fully comprehend. This is evinced in the third and fourth lines, which remark: 'Let us go to Canaan' (line 3) and 'Our forefather's land' (line 4). The tone in lines 3 and 4 reflects both joy and loneliness. Through this text, singers communicate directly with their audience. Both text and melody play complementary roles in the communication process. The singers are longing for and hoping for another world in relation to moments of intense joy and happiness of the present.

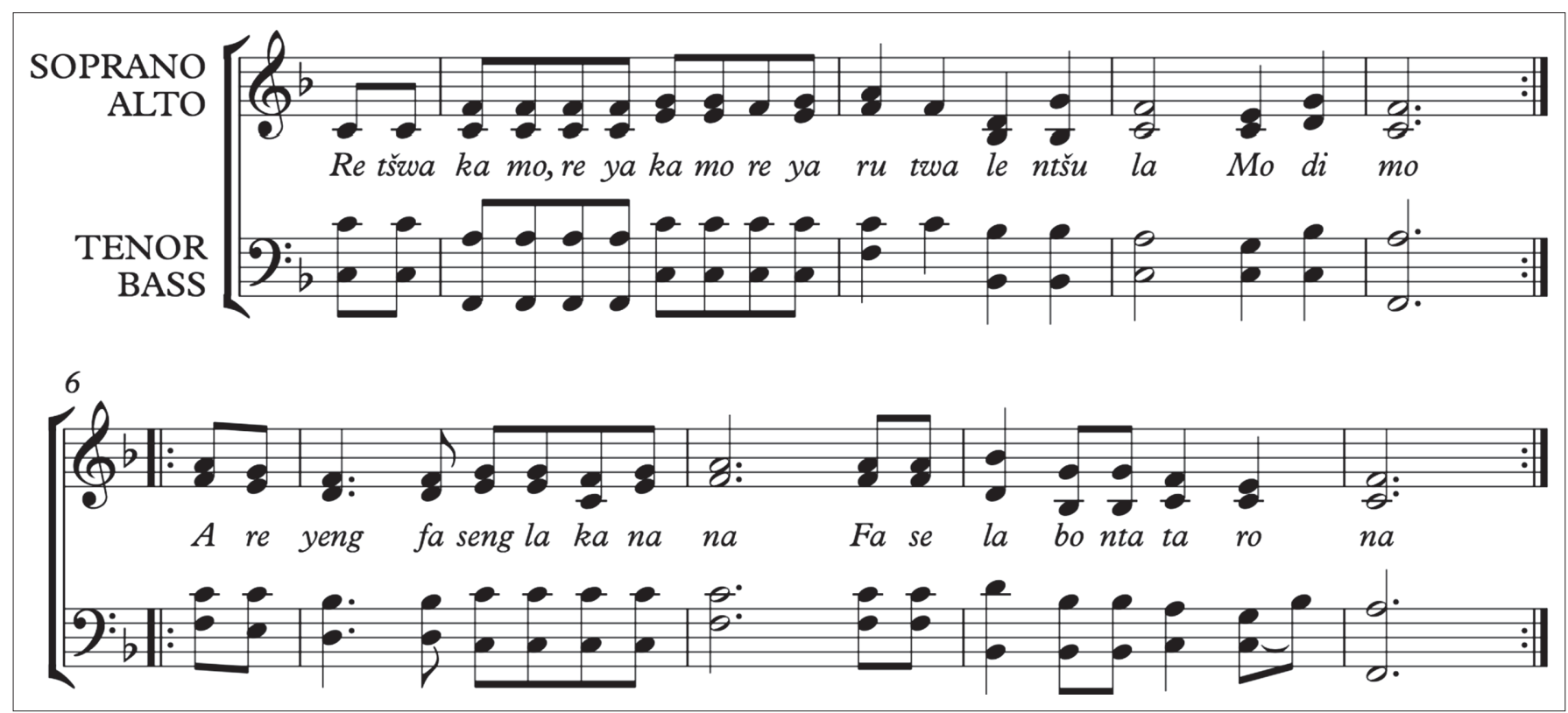

FIGURE 1: 'Re tšwa ka mo, re ya ka mo'. 


\section{Descriptive assessment of 'Ngwanešo o sa diegelang?'}

The second song, 'Ngwanešo o sa diegelang?' ['My brother/sister, why are you undecided?'], is described and analysed below.

As with most traditional Pedi religious songs, the time and a place at which 'Ngwanešo o sa diegelang?' was composed cannot be verified. However, Maria Maloma (born 09 December 1923; pers. comm. 12 January 2008) confirmed that it appeared at the end of the 1930s. Neither the composer, nor the lyricist is known.

The text and translation follows below:

1. Ngwanešo o sa diegelang? [My brother/sister, why are you undecided?]

2. Sokologa o bone Morena [Repent and receive Jesus Christ]

3. Sokologa, sokologa [Repent, repent]

4. Sokologa o bone Morena [Repent and receive Jesus Christ].

The song was recorded by the author on a field trip at Lobethal Church Centre, Sekhukhune area in the Limpopo Province, on 13 January 2008.

The text of the song is given in one brief verse, but is frequently repeated, so that it is made comprehensible and can be internalised easily. It contains a description of the believer's relationship to Jesus, stressing the process of finding and receiving. Moreover, one detects slight associations with mission (e.g. Mt 28:20, as well as hints at missionary conversion). When it is sung, the text has the potential to invite others to live with Jesus as Lord and Saviour, just as the singers do.

When this song is sung, the singers are bending down moving from one side to the other with open arms, thus symbolising the desire to receive Jesus Christ into their life. Whilst singing 'Sokologa o bone Morena' ('Repent and receive Jesus'), they revolve on their own axis to enact the seeking for Jesus at all times and at all places. The singers express their joy over Jesus by clapping their hands.

This way of rendering the song resembles the way of enacting the message of traditional Pedi religious songs. It is a way of reflecting and reproducing the contents of the lyrics, which is very effective in the process of missionary conversion. Text, music and performance combined express and emphasise the receiving of Jesus Christ as the Lord of life, who provides a foundation for life. The contents of the text describe the basics of the Christian faith in an accessible, though rather limited, way and provide a spiritual foundation for life. Often quoting or alluding to biblical verses, recurring themes are to repent and believe in the Lord (Jn 21:17; Jr 4:1-2; Lk 2:30-31; Phlp 2:12; 3:10-11; Col 1:27), and to receive ministry about the Word of God (Ac 16:11-40; Col 1:6b; Ps 22:22; Jn 14:1; Phlp 1:4-5). Thus, using aphorisms and mnemonics, life and faith are summarised and interpreted by means of traditional religious songs. This is done is not done in a theoretical academic discourse, but through singing. The song as a whole is closely integrated by the repetition of key terms. Lines 2 to 4 use the verb sokologa [repent] repetitively, placing a strong emphasis on sokologa.

\section{Summary}

In summary, the two songs are commonplace choruses that borrow from simple primary harmony I-IV-V a la Bach style, a four-part harmonic setting, repetitions and call-andresponse patterns between solo and chorus. These songs, like many in their category, are primarily major in tonality.

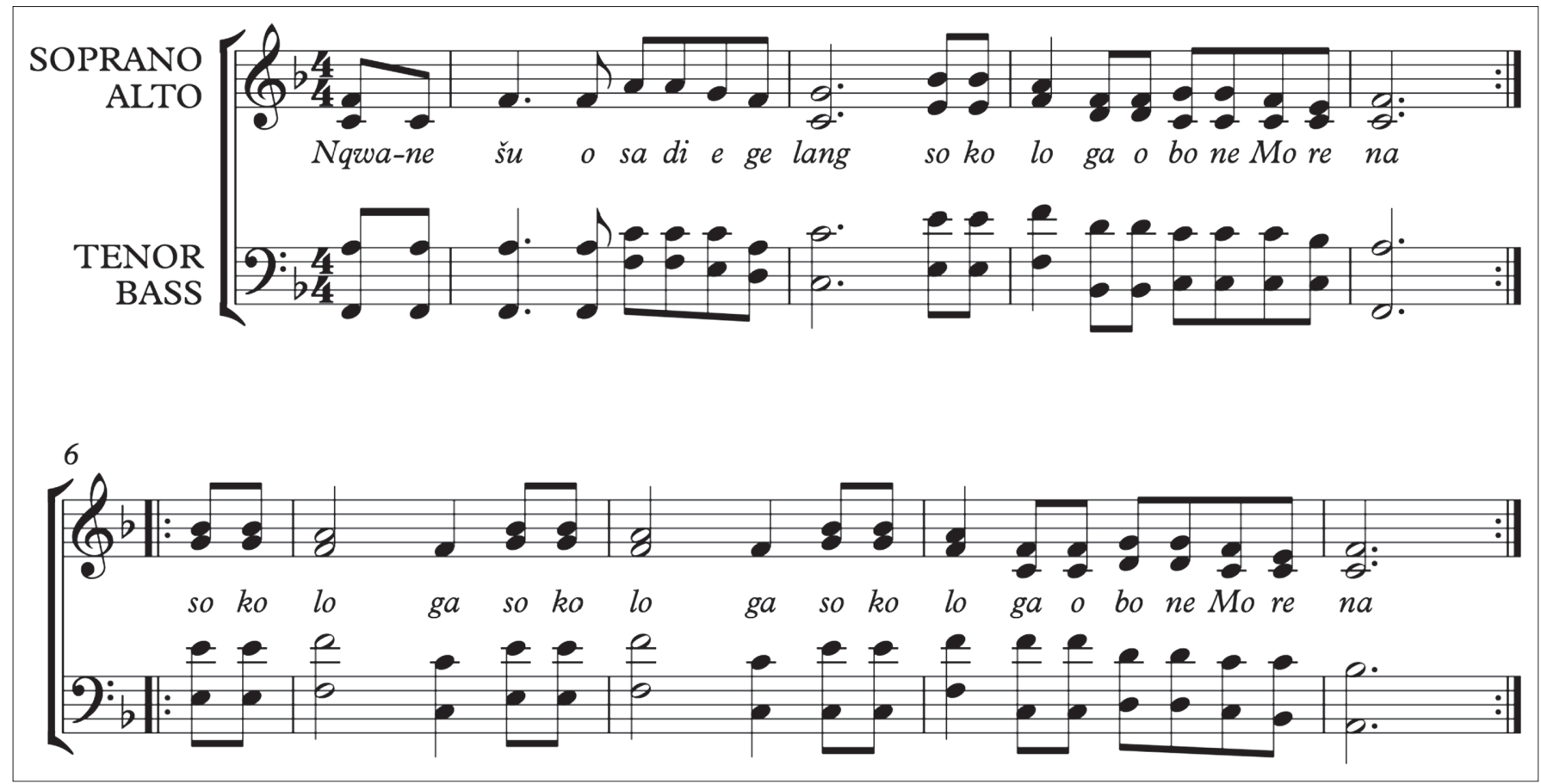

FIGURE 2: 'Ngwanešo o sa diegelang?'. 
The analysis of traditional Pedi religious songs yields the following results:

- These songs have an 'African touch' only through their rather homophonic multi-part singing style.

- The basic musical format of all traditional religious songs is the four-part harmonic setting, which allows all voices, female and male, to participate in the singing, practically and symbolically, and produces a feeling of communal musical expression. Because of the accessible character of the music, its inviting atmosphere discards any performeraudience dichotomy, thus being rather different from the typical Western style choir performances.

- The singing of these songs is, appropriate to their textual content, accompanied by movements and dancing, again characteristic to the African rendition of music.

- The most striking element of these songs is their rhythm as well as in the frequent clapping of hands and dance steps.

These specific features of African music display two results relevant to mission liturgy. On the one hand, the music is a kind of musical syncretism or, as Nketia (1974:17) put it, '[M]usic based on African melodic and rhythmic structures, but exploiting Western harmony and developmental techniques.' On the other hand, that form of African music, especially the emphasis on rhythm, helps the Pedi singers to express themselves and their faith in an appropriate and relevant way. All collected songs follow an antiphonal leader-chorus pattern. Songs thus require a minimum of four people for performance. Conceptually and practically, the Pedi people regard singing as essentially a group activity an opportunity to express their 'communal ethos' (James 2000:176; Bakare \& Mans 2003:217). This view is supported by Maboee (1982:131): 'Traditionally, when Africans worship, they sing and dance together.'

Related to that style of musical expression is the performance of traditional Pedi religious songs. Three elements are essential in the rendition of this form of African church music. The first is that these songs are usually performed by groups of singers, like choirs or congregations, and not by soloists - unless they are warbled in solitude at home (Dargie 1997:321; Kaemmer 1998:707). Hereby, the frequently employed call-and-response form involves everybody to join in the singing.

Secondly, often combined with the choral singing is some kind of dance: slight body movements or expressive dance steps. Dance helps to perform and perceive the music and words of the songs wholeheartedly, almost literally with body and soul. Supportive to this reception of traditional religious songs in its entirety is the rhythmic accompaniment through the clapping of hands and the occasional beating of the hymn book or a small leather cushion (Dargie 1997:325) as well as the playing of meropa [drums] or other percussion instruments that are slowly being introduced in some mainline congregations and are generally very well accepted by the worshippers.
Thirdly, all these elements of rendering traditional religious songs contribute to the essence of traditional religious music. Concerning the issue of special meanings behind the texts, it is noticeable that the contents of the texts of the collected traditional Pedi religious songs describe the basics of the Christian faith and provide a spiritual foundation.

\section{Curricular application}

The application to primary school education was observed when the above-mentioned two songs were used at a primary school. The school principal requested that ethnic Pedi songs be presented when a new school opened. It was decided that the parallelism between traditional and Western music could be bridged by using brass instruments, such as trumpets, tenor horns and baritone euphoniums as well as percussion instruments. Eight Sepedi-speaking children, aged between 10 and 11, from Baxoxele Primary School in Soshanguve (Pretoria), all in the school choir, were observed during music instruction. Music instruction included introduction to techniques of playing brass and percussion instruments; singing and reading music; and improvisation.

Data were collected relating to pupils' musical ability, ability to understand instructions, attitudes towards practice and influences upon it, time spent practising and attainment. Initially, four children found it difficult to produce the sound on the brass instruments, although they had no problems with the percussion instruments. The music instruction lasted 10 weeks, with daily sessions on weekdays only. It is a testament to the simplicity and musicality of these cultural songs that these children could learn to perform them in such a short time. In fact, the children could sing both songs, being only 10 bars each, within the first day of practice. It would not have been achievable with complex Western music. This is a motivation to include these kinds of traditional songs in the primary school curriculum as they can also be performed without instruments.

It was important that each child was able to play $C$ major scale ascending and descending before they could learn how to sight-read 'Re tšwa ka mo, re ya ka mo' and 'Ngwanešo o sa diegelang?'. The children became more confident with time, to the extent that they were able to play the $C$ major scale ascending and descending, and its arpeggio as well as two selected songs for the purpose of performance during the official opening of the school, which was held on 24 August 2013.

The gains observed include an improved concentration and attitude to schoolwork as well as the unlocking of creative talent. Other benefits include improved social skills as demonstrated in an ability to work in a group. Results of the present investigations indicated that learning to play a musical instrument is a complex and time-consuming activity that requires years of dedicated practice and commitment. Consequently, a major challenge for research is to find better and more efficient ways of learning the range of skills required to perform proficiently. 


\section{Discussion}

Ethnographic data from the field indicated that traditional Pedi religious songs, such as 'Re tšwa ka mo, re ya ka mo' and 'Ngwanešo o sa diegelang?', had an inviting nature, a rhythmic foundation, a harmonic simplicity, a capacity of combining intellect and emotion, a repetitiveness and a briefness of musical forms and dogmatic contents.

Closer investigation showed that the data on actual composition was difficult to obtain. The origin of these songs is not known. Naturally, the production of songs does not stop in African societies. New songs emerge with time, just as others are abandoned. Traditional Pedi religious songs have been passed on from generation to generation through oral memory. Much of this process takes place subconsciously at a level where certain acceptable verbal patterns and similar musical patterns coexist, such that attempted differentiation is a futile exercise. Mugenda and Mugenda (1999:202) observe that communities in Africa have traditionally communicated information by word of mouth rather than in written form. They advocate that the older members of the community are considered to have wisdom and it is their obligation to pass on this wisdom to the younger generation. Nurnberger (2007:39) aligns himself with Mugenda and Mugenda by stating that the elderly have received the communal traditions from their forebears and are expected to hand them down to their offspring. He further mentions that it is the elderly that determine the life of the community whilst the youth has to keep quiet and obey. The above observation is supported by Mugambi (1989:94) when he states that the African cultural and religious heritage was passed on orally from generation to generation, and the wisdom of the ancestors was conserved, not in written books, but in songs and oral traditions. The songs used to be transferred orally, but they should now be added to the curriculum to make sure they do not get lost over time.

The results indicate that the skills' transference to the selected children at Baxoxele Primary School had a positive impact on their attitudes, and musical and cultural values. The 'Arts and Culture' educators at the school introduced the author to the 'Arts and Culture' curriculum that distributes music education to children in the classroom. This new curriculum poses some interesting concepts that question the role of socalled 'traditional' music in the music classroom. This case study found the two short choruses that the children learned appropriate for the learning area 'Arts and Culture'. The results of this article imply that if the curriculum is observed as designed, it could contribute to the musical culture of the learners however distinct from one another.

\section{Conclusion}

Results from this article indicate that for the preservation of traditional Pedi religious music and culture there is an urgent need for the collection of traditional Pedi religious songs. Following discussions on the relative importance of traditional Pedi religious songs, it is evident that through enculturation, Pedi music tradition gains its stability, since members of one generation teach to members of succeeding generations what Pedi traditional religious music is and does. After analysis of the data collected from the two case studies, we are beginning to understand what learning models, processes and methods are appropriate for collecting and analysing traditional Pedi religious songs and for teaching these songs in the primary school's setting. Similar projects could be undertaken in the other 10 language groups in South Africa to diversify cultural experience and value systems within primary school music education.

In view of the above findings, this study concludes with some suggestions:

- Further investigations should be conducted with regard to the collection, retention and transmission of traditional Pedi religious songs so as not to forever lose these important cultural treasures.

- This will enrich education, Pedi cultural and religious values, and indigenous knowledge It will also ensure the preservation of Pedi cultural heritage.

- Further research into the function of traditional Pedi religious songs will advance the wealth of people's religious well-being in difficult life situations.

\section{Acknowledgements Competing interests}

The author declares that he has no financial or personal relationship(s) that may have inappropriately influenced him in writing this article.

\section{References}

Agbeti, J.K., 1972, African Theology, Afropress, Nairobi.

Akuno, E.A., 2005, 'The role of research in music education', East African Journal of Music 1, 64-77.

Bakare, O.R. \& Mans, M., 2003, 'Dance philosophies and vocabularies', in E. Herbst, M. Nzewi \& K. Agawu (eds.), Musical arts in Africa, pp. 215-235, Unisa Press, Pretoria.

Balasuriya, T., 2002, 'Liberation of the affluent', Black Theology: An International Journal 1(1), 83-113.

Boas, F., 1906, 'Some philosophical aspects of anthropological research', Science 23(591), 641-645. http://dx.doi.org/10.1126/science.23.591.641

Boas, F., 1920, 'The methods of ethnology', American Anthropologist 22(4), 311-321. http://dx.doi.org/10.1525/aa.1920.22.4.02a00020

Burton, S.H. \& Chacksfield, C.J.H., 1979, African poetry in English: An introduction to practical criticism, Macmillan Press, London.

Campbell, P.S., 2002, 'The musical cultures of children', in L. Bresler \& C.M. Thompson (eds.), The Arts in children's lives, pp. 57-69, Kluwer Academic Publishers, Dordrecht, Boston. http://dx.doi.org/10.1007/0-306-47511-1_5

Codere, H., 1966, 'Introduction', in F. Boas (ed.), Kwakiutl ethnography, pp. xi-xxxii, University of Chicago Press, Chicago.

Dargie, D., 1997, 'South African Christian music. Christian music among Africans', in R. Elphik \& R. Davenport (eds.), Christianity in South Africa - A political, social \& cultural history, pp. 319-326, James Currey / David Phillip, Oxford / Cape Town.

Du Toit, C., 1998, 'African Hermeneutics', in S. Maimela \& A. Konig (eds), Initiation into theology. The rich variety of theology and hermeneutics, pp. 373-398, J.L. Van Schaik, Pretoria.

Fontana, A. \& Frey, J.H., 1994, 'Interviewing the art of science', in N. Densin \& Y. Lincoln (eds.), The Handbook of Qualitative Research, pp. 361-376, Sage Publications, London.

Frankle, J.R. \& Wallen, N.E., 1993, How to design and evaluate research in education, McGraw-Hill, New York.

James, D., 2000, 'Sister, spouse, lazy woman: Commentaries on domestic predicaments by Kiba performers from the Northern Province', in D. Brown (ed.), Oral literature and performance in Southern Africa, pp. 176-194, James Currey Ltd., Oxford. 
Joseph, D. \& Van Niekerk, C., 2007, 'Music education and minority groups cultural and musical identities in the "newer" South Africa: White Afrikaners and Indians', Intercultural Education 18(5), 487-499. http://dx.doi.org and Indians', Intercultural

Kaemmer, J.E., 1998, 'Southern Africa - An introduction', in I. Garland (ed.), The Garland Encyclopedia of World Music, pp. 700-721, Alexander Street Press, New York / London.

Karolyi, O., 1998, Traditional African and Oriental music, Penguin, London.

Kgasa, M.L.A. \& Tsonope, J., 1995, Thanodi ya Setswana, Longman Botswana, Gaborone.

Kwami, R.M., Akrofi, E.A. \& Adams, S., 2003, 'Integrating Musical Arts Cultures', in A. Herbst et al. (eds.), Musical Arts in Africa, pp. 261-278, University of South Africa Press, Pretoria.

Lapointe, E., 1995, '"Motho" - The Basotho traditional thinking', Mission - Journal of Mission Studies 2(2), 253-278.

Lesser, A., 1981, 'Franz Boas', in S. Silverman (ed.), Totems and teachers: Perspectives on the history of anthropology, pp. 1-23, Columbia University Press, New York.

Levine, L., 2005, The Drumcafe's traditional music of South Africa, Jacana Media, Johannesburg.

Maboee, C., 1982, Modimo Christian Theology in Sotho Context (Preliminary Publication), Lumko Institute, Pietermaritzburg.

Mbiti, J.S., 1969, African religions and philosophy, Heinemann Educational Books, London.

Mönnig, H.O., 1967, The Pedi, J.L. van Schaik, Pretoria.

Mouton, J., 2001, How to succeed in your master's and doctoral studies. A South African guide and resource book, J.L. Van Schaik, Pretoria.

Mugambi, J.N.K., 1989, African heritage and contemporary Christianity, Longman Kenya, Nairobi.

Mugambi, J.N.K., 1994, African Christian Theology, East African Educational Publishers, Nairobi.
Mugenda, O.M. \& Mugenda, A.G., 1999, Research methods: Quantitative and qualitative approaches, Acts Press, Nairobi.

Nketia, J.H.K., 1974, The music of Africa, W.W. Norton \& Co., New York.

Nurnberger, K., 2007, The living dead and the living God. Christ and the ancestors in a changing Africa, Cluster Publications, Pietermaritzburg.

Nzewi, M., 2005, Learning the musical arts in contemporary Africa: Informed by Indigenous Knowledge Systems, Centre for indigenous instrumental African music and dance, Ciimda, Pretoria.

Oosthuizen, G.C., 1976, Afro-Christian religion, Brill, Leiden.

Potgieter, H., 2006, 'Mapping the journey', in H. Potgieter (ed.), The transformation of Musical Arts Education: Local and global perspectives from South Africa, $\mathrm{pp}$. iv-x, North-West University, Potchefstroom.

Rohner, R. \& Rohner, E., 1969, 'Franz Boas and the development of North American ethnology and ethnography', in R. Rohner (ed.), The Ethnography of Franz Boas, pp. xiii-xxx, University of Chicago Press, Chicago.

Smith, M., 1959, 'Boas' "natural history" approach to field method', in W. Goldschmidt (ed.), The anthropology of Franz Boas: Essays on the centennial of his birth, pp. 46-60, Krause Reprint Company, Hudson.

Snyman, J.W., Shole, J.S. \& Le Roux, J.C. (eds.), 1990, 'Dikišinare ya', in Setswana English Afrikaans Dictionary Woordeboek, pp. 1-527, Via Afrika Limited, Pretoria. Spradley, J., 1980, Participant Observation, Holt Rinehart \& Winston, New York.

Stocking, G.W. (ed.), 1974, The shaping of American anthropology 1883-1911: A Franz Boas reader, Basic Books, New York.

Stocking, G.W., 1979, 'The intensive study of limited areas: Toward an ethnographic context for the Malinowskian innovation', History of Anthropology Newsletter 7(2), 9-12.

Van der Hooft, A.G., 1979, De Malopodans, Rodopi, Amsterdam.

Westerlund, H., 1999, 'Universalism against contextual thinking in multicultural music education - Western colonialism or pluralism', International Journal of Music education (33), 94-103. http://dx.doi.org/10.1177/025576149903300111 